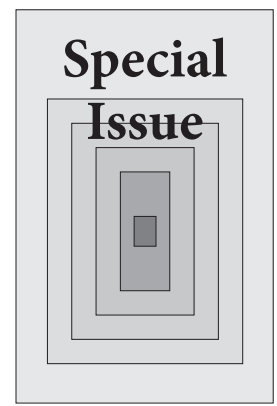

\title{
Work-Family Balance of Families with Small Children: How to Achieve Gender Equality in Parenting
}

Capabilities to Combine Work and Family in the Netherlands: Challenging or Reinforcing the One-and-a-half Earner Model?

\author{
Laura den Dulk and Mara A. Yerkes
}

\begin{abstract}
In this article, we assess the extent to which national-level work-family policies in the Netherlands enable various groups of working parents (men versus women, low versus highly educated, and dependent employees versus self-employed) to combine work and care. We answer this question by conducting a policy analysis using Sen's (1992) capability framework. Applying this perspective, we evaluate the availability, accessibility and design of work-family policies in the Netherlands. Moreover, we consider the importance of collective agreements and the organizational context. Our analysis shows that current work-family policies and collective agreements in the Netherlands offer certain groups greater capabilities to reconcile work and care than others. Childcare policy offers less accessibility for the self-employed and flexible work arrangements enable women more than men to take on care tasks and work part-time. In addition, higher educated individuals have greater access to flexible work arrangements than lower-educated workers, but often use this flexibility to work more rather than reconcile work with care. Moreover, current care leave policies enforce rather than challenge existing socio-cultural norms, and alternatives to the one-and-a-half earner model remain limited.
\end{abstract}

Key words: work-family policies, the Netherlands, capability approach

2016, Japanese Journal of Family Sociology, 28(2): 180-192

\section{Introduction}

In the past few decades, national governments have increasingly introduced and developed work-family policies to support working parents combining paid work and family life, such as parental leave, public childcare, and the right to reduce working hours. While work-family policies are prevalent across most developed countries, large variations exist with respect to the nature and amount of policies (den Dulk and Peper 2016). In the Netherlands, work-family policy development started relatively late, during the 1990s.
From a comparative perspective, the Dutch policy context is characterized by relatively short leave policies, the part-time use of public childcare services, and policy support for reducing working hours as a strategy for reconciling work and family life. In fact, part-time employment is very common in the Netherlands, in particular among women (Yerkes 2009). Presently, 77\% of working women has a part-time job, compared to $26.4 \%$ of working men (Merens and Van den Brakel 2014). This is by far the highest proportion in Europe. With women more likely to work part-time, the oneand-a-half earner family model, in which the man

\footnotetext{
Laura den Dulk: Department of Public Administration and Sociology, Faculty of Social Sciences, Erasmus University Rotterdam, P.O. Box 1738, 3000 DR Rotterdam, the Netherlands

E-mail: dendulk@fsw.eur.nl

Mara Yerkes: Department of Interdisciplinary Social Science, Utrecht University, P.O. Box 80140, 3508 TC, Utrecht, the Netherlands

E-mail: M.A.Yerkes@uu.nl
} 
works full-time and the woman part-time, has become the dominant family model among Dutch parents with children (Merens and Van den Brakel 2014).

Recently, the combination of paid work and care received renewed attention in the Netherlands. Within the context of an aging society, welfare state reforms, and in particular spending cuts in the health care sector, citizens are under increased pressure to provide informal care for others alongside their paid job (Merens and Van den Brakel 2014). As a result, policymakers have sought ways of supporting such work-care reconciliation, such as time/spatial flexibility. The recently accepted law on Modernizing Leave and Working Times (2015) is an example of this trend. At the same time, the low rate of economic independence among many Dutch women remains a concern, a consequence of the high rate of part-time work. As in other countries, the division of paid work and care is highly gendered within the Dutch context. In addition, differences in reconciliation strategies vary according to the educational level of working parents (Merens and Van den Brakel 2014; Van Wel and Knijn 2006). In addition, the Netherlands has witnessed a recent increase in self-employment, among women in particular. Many women feel self-employment makes it easier to combine work and family life (Annink and den Dulk 2012), despite the self-employed not having full access to many national work-family policies (Annink et al. 2015).

Given this background, the central question raised in this article is: To what extent do current work-family policies in the Netherlands enable the combination of paid work and care among different groups of working parents (men versus women, low versus highly educated, and dependent employees versus self-employed)? Amartya Sen's (1992) capability and agency approach, which has recently been applied in the work-family field (Hobson 2011, 2014), provides a valuable framework for studying the impact of policies within their cultural context. In the capability framework, what matters is not only what people do (their number of working hours or whether they actually use existing work-family policies) but also what freedoms they have and what choices they would make if they had the capabilities to lead the kind of lives they want. The capability framework does not define an optimal way to combine work and family life, rather it is about being 'able to choose a life one values' (Hobson et al. 2011: 171). We discuss this approach in the next section, applying it to work-family policies. We then outline the most important work-family policy indicators to conduct a policy analysis based on the capability approach.

\section{The Agency and Capabilities Approach}

The capabilities approach is a theoretical and normative approach that offers the possibility to evaluate current work-family policies in the Netherlands (Robeyns 2005). Central to this evaluation is the question whether and how policies enable people to combine work and family life. Sen (1992) argues within this approach that social inequality is the result of individual differences in freedoms to achieve various outcomes. Assessing capabilities means looking at "which opportunities members of society actually have and how these are divided" (Van der Klink et al. 2011: 346). Increasing individual wellbeing is key within this framework (Robeyns 2005). When applying this approach to the work-family interface, capabilities refer to the freedoms that people experience in combining paid work and caring responsibilities in various ways (Hobson 2014; Korpi et al. 2013). By extension, freedom and agency are related to access to and the ability to use existing policies (Hobson 2014).

Individual freedom to achieve a given outcome (functioning) depends on resources, to use Sen's term (Robeyns 2005). Applying this idea to work and family, work-family policies can enable people to combine 
paid work with care for children. However, people are not always able to use existing resources. Research shows for instance, that despite a need for leave, people do not always make use of existing leave arrangements (Luijn and Keuzekamp 2004; De Vries and Van der Mooren 2011). The unpaid character of leave or a fear of career consequences when taking leave may form a barrier to the actual utilization of leave policies. The ability to use resources, i.e. the actual freedom and ability to make choices, depends on so-called conversion factors (Hobson et al. 2011). A distinction can be made between conversion factors at the individual, societal, and institutional level (Hobson 2014).

The concept of conversion factors is best explained using an example related to work and care. Theoretically, formal childcare allows parents to outsource care for their children. However, when parents lack the financial means to utilize formal care (individual factor), when demand exceeds the supply of childcare resulting in long waiting lists (institutional factor), or when childcare is seen as detrimental to children's wellbeing (societal-cultural factor), use of formal care will be limited. This example indicates that converting resources into a capability to reconcile paid work and care demands can be constrained by individual, societal-cultural and institutional factors. The resources people have, in combination with these conversion factors leads towards a certain capability set (Robeyns 2005). The capability set is the framework in which people make choices. This framework is central to the current policy analysis. We do not focus on outcomes - i.e. how people actually combine work and care. Rather, we evaluate the frameworks in which different groups in society can make choices in relation to the combination of work and care for children. We now elaborate further on the relevant individual, societalcultural and institutional factors.

\section{Individual factors}

The freedom to make choices and the alternatives people have to combine work and family life are related to individual factors like gender, age, ethnicity and social class (Hobson 2014). Gender determines to a large extent individual choices regarding work and family life (Crompton 2006; Gornick and Meyers 2004). The choices men and women make regarding paid work and childcare responsibilities are shaped by dominant gender norms regarding the roles of men and women in the household and related tasks (in particular among heterosexual couples) (Bianchi et al. 2000; Grunow et al. 2012). These gender roles often become more traditional once children are born (Neilson and Stanfors 2014). In the Netherlands, the division of household and care work is also related to the level of parents' education (Van Wel and Knijn 2006). While gender is a key factor in shaping individual's abilities to reconcile work and care, a number of studies increasingly point out the importance of the intersection between gender and social class (Korpi et al. 2013; Misra et al. 2011; Hegewisch and Gornick 2011). In contrast to Hobson (2014), we therefore not only emphasize the relevance of gender but also social class and employment status. Self-employed persons do not always have the same access to work-family policies as employees (Annink et al. 2015). On the other hand, the self-employed often have more control over when and where they work compared to employees (Annink and den Dulk 2012, 2014).

\section{Societal-cultural factors}

Hobson (2014) distinguishes a number of conversion factors at the societal level, including norms and values, social movements and the media. Social-cultural norms largely determine the choices made by individuals regarding work and care (Kremer 2006). These norms are time and context dependent (Aboim 2010) and a reciprocal relationship between social norms and 
behaviour often exists. On the one hand, existing beliefs about the roles of men and women affect the way in which work-family policies are used. For example, if women are considered responsible for the care of children they are more likely to use part-time work or parental leave than men (Fahlén 2014). In this manner, policies are a reflection of existing norms and values. On the other hand, existing beliefs about gender roles can shape the design of policy, challenging existing standards and initiating change. Whether norms are reflected in policy or challenge existing policies depends on the institutionalization of policies. In more embedded policy fields such as unemployment, attitudes and values are a reflection of policy. In newer policy areas where policies are still in development, such as active labour market policies, policy appears to adapt to the prevailing public opinion (Raven et al. 2011).

Gendered norms regarding work and care have slowly changed in the Netherlands. While full-time motherhood was the norm for a long time, this ideal gradually shifted into a combination ideal in the 1990s, centred on a combination of (part-time) paid work and care (Kremer, 2006). Regarding the embeddedness of Dutch work-family policies, it is likely that during the early development of work-family policies in the early 1990s, traditional views prevailed, influencing the design of work-family policy. Greater attention for an equal division of work between men and women only occurred later on with the introduction of the socalled combination model, in which mothers and fathers were assumed to be equally involved in paid work and care (den Dulk 2001; Kremer 2006).

Work-family policies are now deeply embedded in Dutch social policy. However, as our analysis will show, the Dutch policy framework does not yet actively seek to overcome existing gender roles. This contrasts with the introduction of the so-called "daddy quotas" in Scandinavian countries for example, which challenge gender norms by dedicating a certain proportion of paid parental leave exclusively for fathers (Haas and Rostgaard 2011). In our analysis, we examine the attitudes of different groups in society regarding the roles of men and women in relation to the combination of paid work and care. An analysis of the role of social movements and the media is beyond the scope of this article.

\section{Institutional factors}

At the institutional level, Hobson (2014) argues that the design of policies impacts the extent to which it can be converted into capabilities. Key to understanding the availability of and access to work-family policy is assessing whether the policy is formulated as a legal right, as part of a collective agreement and whether employers are able to deviate from existing arrangements (with or without consulting employees). In addition, in relation to leave and childcare provisions, financial compensation is relevant to actual use (Hobson et al. 2011). Hobson further discusses the organizational context and time/spatial flexibility (Hobson 2014). Flexibility in working hours and the location of work plays an important role in combining work and care. Employee control over when and where to work is imperative if flexibility is to benefit the combination of work and family life. In the Netherlands, the introduction and development of various ICT and communication technologies inspired many Dutch organizations to introduce so-called 'new ways of working' (Het Nieuwe Werken or HNW in Dutch), resulting in increased attention for time/spatial flexibility (Peters et al. 2009). The downside of flexibility in time and place, however, is that the boundaries between work and private life become increasingly blurred and permeable, which can have negative consequences for employees (MacEachen et al. 2008). In addition, spatial flexibility is not possible in all occupations (Smulders et al. 2011). Much low-skilled work is not portable; 
hence, low-skilled workers are less likely to benefit from this new form of flexibility compared to higher educated knowledge workers.

The organizational context also influences the opportunities parents have to combine work and care. For example, in organizations in which a "long-hours culture" prevails, and in which performance is often decisive for wages, employees may refrain from taking leave or working reduced hours. An example of this long-hours culture affecting work-care reconciliation can be found in Japan (Takahashi et al. 2014). In contrast, a supportive organizational culture can increase the sense of entitlement to use work-family policies (Thompson et al. 1999; Peper et al. 2009). Moreover, managerial support is crucial in shaping employee's capabilities to use work-family policies (den Dulk et al. 2011).

The organizational context can be shaped by collective agreements. Collective agreements can substitute, supplement or restrict existing policies (Ollier-Malaterre 2009; Yerkes and Tijdens 2010). Within the Dutch context, collective agreements in the public sector are more likely to complement existing policies than collective agreements in the private sector (de la Croix et al. 2014; Yerkes and Tijdens 2010). It is also possible to deviate from existing legislation within some work-family policies. Within our analysis, we account for the organizational context by examining collective agreements and the attitudes of employers regarding the use of work-family policies. By including collective agreements in our analysis, we are emphasizing the ways in which collective agreements can complement or even act as an alternative to work-family policies.

Summing up, by applying the capability approach we can evaluate to what extent existing work-family policies - in terms of availability, accessibility and design - enables various groups of working parents to combine work and care. To do this, we need to focus on whether and how working parents are able to convert resources - embodied in work-family policiesinto capabilities. Whether they are able to do this depends on individual, institutional and societal factors (conversion factors). In doing so, we attempt to provide insights into the extent to which working parents have real choices in combining work and care, as well as the scope of alternatives they have.

\section{Method and Measurement}

We apply the capability framework by conducting a policy analysis. The policy analysis is based on relevant policy indicators as identified within the work-family field: leave, childcare and flexible work arrangements (den Dulk et al. 2013). A distinction is made between the availability, accessibility and design of these workfamily policies (Korpi et al. 2013). To take account of the different capabilities across various groups, we consider possible differences between men and women, higher and lower educated, and between the self-employed and dependent employees.

Work-family policies and collective agreements are measured using existing literature and data. Firstly, we evaluate public childcare provisions. We examine the provision of formal childcare (availability), financing (accessibility) and the quality and affordability (design). We apply the logic of Korpi and colleagues (2013) to the Dutch situation by evaluating the financing, supply and cost of childcare for 0-3 year olds (day care provision) and 4-12 year olds (after-school care).

Second, we evaluate maternity leave, parental leave and paternity leave. Availability and accessibility are measured by considering whether leave exists and who is entitled to the leave (Korpi et al. 2013). In addition, it is necessary to consider the design of the leave (duration), and whether the payment is means-tested. Since the design of parental and paternity leave policies is related to the likelihood that fathers will make use of leave (Fox et al. 2009; Haas and O'Brien 2010), we also 
look at the length and affordability of leave (amount of payment).

Finally, flexible work arrangements and the laws and regulations on working hours also influence how working parents are able to combine work and care. Here we look at the question of how flexible working arrangements are regulated and the extent to which people have access to flexible working arrangements. For the latter we consider flexible start and finishing times, the amount of working hours, and the ability to work from home (telework) as it exists in both legislation and collective agreements. The design of flexible work policies and arrangements can also be important. Policy design refers to the degree of control working parents have over when and where they work. Before presenting our findings, we discuss the social-cultural norms regarding gender roles and the division of paid work and care.

\section{The Policy Analysis}

\section{Social-cultural norms regarding the combina- tion of work and family life}

Since the 1980s, there has been a shift from the male breadwinner model to a one-and-a-half earner model in the Netherlands (Visser 2002; Kremer 2006). Yet while an increasing number of Dutch parents would prefer an equal division of paid and unpaid work, they do not always manage to achieve this (Merens and Van den Brakel 2014). In reality, the combination of two full-time jobs or two large part-time jobs among couples with young children is rare. The dominance of the one-and-a-half earner model is reflected in Dutch social-cultural norms regarding work and care. For example, Dutch citizens generally consider a 2 to 3 -day workweek ideal for mothers with young children (0-4 years). For fathers of young children, a 4-day workweek is considered ideal (Merens and Van den Brakel 2014). Many people still regard women as most suitable for caring for young children ( $42 \%$ of men versus
$23 \%$ of women). The acceptance of the use of childcare has increased in the Netherlands. Most parents, however, use childcare part-time. Full-time use of formal childcare is rare.

While Dutch citizens increasingly accept that women and particularly mothers work outside the home, these attitudes vary by educational level. Based on the 2010 European Social Survey (ESS 2010), we see that more than one-third of Dutch men (37\%) and women (39\%) with a low level of education agree or strongly agree with the statement that women must be willing to work less for the sake of the family. Among highly educated men and women these percentages are 22\% (men) and 19\% (women) respectively. These significant differences in attitudes do not exist between employees and self-employed workers. The ESS data show that $26 \%$ of employees agree or strongly agree with the above statement. Among the self-employed, this percentage is slightly higher, $32 \%$, but the differences are not significant.

In sum, cultural norms in the Netherlands are still focused on a one-and-a-half earner model, with women working part-time and doing most of the caring. Men have either a full-time job or a substantial parttime job. Work-family policies can either reinforce or challenge these expectations, thereby improving or restricting the capabilities of working parents to combine work and family life. We start by looking at childcare.

\section{Childcare}

The availability of formal childcare has grown significantly in recent years (Yerkes 2014). After a series of stimulation measures, the Childcare Act came into force in 2005. Previous childcare shortages disappeared and currently few to no waiting lists exist and parents have a large number of childcare centres to choose from in their immediate environment (Portegijs et al. 2014). According to data from Statistics Netherlands (2001-2013, CBS 2015), the number of day 
care places available for $0-3$ year olds (for at least 5 consecutive hours per day) increased significantly in recent years in both absolute and relative terms. While only 83,000 places were available in 2001 (10.2\% of 0-3 year-olds), this increased to 209,000 places by 2013. Thus, space exists for $28.8 \%$ of $0-3$ year olds in formal day care. However, the number of places declined slightly after 2012 given changes to childcare allowances, something which might change once again given the increase in childcare allowances introduced in 2016. The increase in childcare availability is even more spectacular for 4-12 year olds: from 40,000 places in 2001 to 225,000 places in 2013 . The relative increase (as a percentage of the number of 4-12 year olds in the Netherlands) went up from $2.2 \%$ in 2001 to $12.9 \%$ in 2013. In contrast to the slight decrease in childcare places for $0-3$ year olds, no decline is (yet) visible regarding the number of places available for 4-12 year olds.

The increase in formal childcare makes it theoretically possible for all parents to use childcare, regardless of education or employment status. Use of formal childcare, however, strongly depends on childcare funding (accessibility) as well as childcare quality and cost (design). Although the quality of childcare for 0-3 year olds has risen in recent years, only $12 \%$ of institutions providing formal care are currently evaluated as being of "good" quality (Fukkink et al. 2013; Portegijs et al. 2014). Childcare has also become more expensive in recent years and since 2008, usage is declining (CBS 2014b; Portegijs et al. 2014). In 2012, 16\% of parents who had their first child and $14 \%$ of parents with school-age children did not use formal childcare even though they would like to do so, citing increased costs of care. Only a small group of parents mentions quality of care as a reason to make less use of childcare (Portegijs et al. 2014).

Alongside changes in quality and cost, the accessibility of childcare has changed frequently in recent years. Parents receive an income-tested childcare allowance from the Tax Office, which includes a contribution from both government and employers, reimbursing parents for part of actual childcare costs based on a maximum hourly rate set by the government. This rate may be higher in reality. While parents who used formal childcare (nursery, child minder or after school care) in 2008 were reimbursed for $81 \%$ of the costs, in 2013, this dropped to $63 \%$. Households with higher incomes (combined income of 118,189 Euros or more) became ineligible to receive financial compensation in 2013.

The increased cost of childcare is especially problematic for low-income parents. Research shows that households with higher incomes make greater use of formal childcare than households with lower incomes (de Vries and van der Mooren 2011). The question is whether this difference occurs because households with higher incomes can more easily afford to outsource care or because they work longer hours. Both of these factors are likely to play a role. For example, Korpi and colleagues (2013) show that childcare provision is less relevant for the employment rates of highly educated women compared to lower educated women.

Self-employed persons are also eligible for the childcare allowance, which increases accessibility for this group. However, the childcare allowance is based on actual hours worked, something which can vary from year to year for the self-employed. This design of childcare policy may result in uncertainty among the selfemployed, particularly among the own account selfemployed with lower earnings. If they work fewer hours than anticipated, they run the risk of having to repay the allowance (Annink and den Dulk 2014). This may cause them to refrain from making use of formal childcare.

\section{Leave}

Under current legislation, employees with young 
children are entitled to 26 weeks of unpaid parental leave. Mothers are also entitled to 16 weeks paid maternity leave and fathers are entitled to two days of paternity leave. With the introduction of the Act Modernization of Leave and Working Hours in 2015, paternity leave was extended by three days of (unpaid) leave, taken from parental leave. The current government plans to extend paternity leave to five days paid leave in 2017.

The design of leave policies can inhibit take-up. In the Netherlands, because parental leave and part of paternity leave are unpaid, not everyone can afford to take leave. However, collective agreements can supplement national legislation (Yerkes and Tijdens 2010) and research from the 100 largest collective agreements in the Netherlands shows that 15 agreements include partially paid parental leave. The majority (12) of those agreements apply to the government and health care sector. Paternity leave provisions deviate from the law in some cases (12 agreements provide only one day off) and supplement legislation in others (15 agreements provide longer leave, usually 5 days) (de la Croix et al. 2014).

Despite the growth in the availability of leave arrangements for working parents, differences in accessibility remain. Freelancers and self-employed pregnant women can make use of the Independent and Pregnant (ZEZ) scheme, which entitles women to 4 to 6 weeks of leave before birth and 10 weeks postpartum. The allowance is provided at minimum wage and therefore does not offer full earnings replacement as is the case for pregnant dependent employees (Annink and den Dulk 2014). The self-employed do not have access to parental and paternity leave. For self-employed workers, leave is less appropriate to facilitate the combination of work and care, since taking up leave may jeopardize the continuity of the business. Few differences exist between high and low-educated workers, but appear mostly in the take up of leave. Highly educated mothers take parental leave more often than less educated mothers. Working mothers use parental leave more often than working fathers: in 2013, 57\% of entitled mothers took leave, compared to $23 \%$ of fathers. The number of mothers taking parental leave is increasing, while fathers' use of parental leave stagnated in recent years (Merens and Van den Brakel 2014). Most people cite financial reasons and fears of missed career opportunities for not taking leave despite needing it (de Vries and van der Mooren 2011).

\section{Flexible work arrangements}

Changes in laws and regulations have increased the availability of flexible work arrangements in the past 15 years in the Netherlands. In 2000, the Dutch government introduced the Working Hours Adjustment Act in an attempt to stimulate the development of flexible working hours. This law gave employees the opportunity to submit a request to reduce or extend their working hours, thereby giving employees the right to adapt their working hours to their personal needs if it does not interfere with serious business needs. Access is limited to employees who have been with their employer for at least one year and work at an organization with 10 or more employees. The legislation more strongly supports a reduction of working hours rather than an extension. The latter can be restricted via collective agreements. Research shows that nearly half of employers is positive about part-time work at all job levels and that employers rarely reject a request to reduce working hours. Requests to extend working hours are less common, however, and not always granted (Van Echtelt et al. 2015). Flexible working is further encouraged by the Modernization Leave and Working Time Act (2015). This new law also includes the right to submit a request for flexible working hours (flexible start and finishing times) and to work from home, similar to the adjustment of working hours.

The design of flexible work arrangements in the 
Netherlands (the right to reduce or extend working hours and the protection of the rights of part-time workers) potentially creates significant agency freedom to combine work and family life. In practice, mainly women use existing entitlements to reduce their working hours. In female-dominated sectors, employers consider the reduction in working hours a personal decision. Support for expanding working hours when care responsibilities decrease as children get older is rarely offered (Keuzenkamp et al. 2009). Part-time work is the main strategy for women to combine work and care responsibilities. This means that individual factors (such as gender) and social-cultural factors (norms) ensure that the freedom offered by flexible working arrangements particularly enables women more than men to care for children and to work parttime.

Collective agreements may also contain flexible work arrangements. Research among the 100 largest collective agreements in the Netherlands shows that two-thirds of collective agreements include a statement that the employer should take the personal circumstances of employees into account in regards to their working hours. However, the majority of collective agreements indicates that organizational interests have priority over employee preferences. Only three collective agreements contain an arrangement on self-scheduling, which offers employees the most possibilities to adapt working hours to care tasks (De la Croix et al. 2014).

An indicator of the degree of accessibility is the extent to which workers report that they can vary their start and end times. In 2012, $40 \%$ of employees reported having the ability to vary their working hours compared to $36 \%$ in 2002 (Vlasbloem et al. 2015). Of the 100 largest collective agreements in the Netherlands, 21 also contain a teleworking arrangement. Moreover, evidence from Dutch employers shows that the proportion of organizations that allow teleworking has increased between 2003 and 2014 to 38\%, particularly in the public and private services. However, there appears to be a stagnation in this rising trend since 2011 (Van Echtelt et al. 2015). Workers report lower percentages of working at home than employers (18\% in 2012, up from $13 \%$ in 2002). This lower percentage is related to the fact that not every job lends itself to teleworking. In addition, managers within organizations differ in the degree to which they actually allow teleworking (den Dulk and De Ruijter 2008; Peters et al. 2010). On average, men make more use of the option to work from home than women and teleworking increases with level of education. These differences correspond to the primary reason most employees work from home, which is to finish work ( $43 \%$ ) more so than to combine work and care (12\%) (Smulders et al. 2011).

Compared to employees, self-employed workers often have more flexibility to arrange their own working hours. The idea that self-employment allows more autonomy and flexibility is a frequently mentioned reason for many mothers to exchange regular work for a living as a freelancer (Foley 2015). However, the extent of perceived autonomy among self-employed women in the Netherlands is not identical. It varies depending on the sector in which they work and their work experience (Annink and den Dulk 2012).

\section{Conclusion and Discussion}

In this article, we evaluated to what extent workfamily policies in the Netherlands enable working parents to combine paid work and care for children by using the capability framework of Sen (1992) as applied by Hobson $(2011,2014)$. Applying this approach emphasizes the access to and the right to work-family policies as well as the ability to make use of these policies. We looked in particular at the availability, accessibility and design of childcare, leave policies, and flexible work arrangements. The extent to which resources 
(work-family policies) can be converted into capabilities is influenced by individual factors. Therefore, we examined differences in gender, education level and employment status. In addition, we have paid attention to societal-cultural factors (norms and values) and institutional factors (the organizational context and collective agreements).

The analysis shows how work-family policies and collective agreements give some working parents more freedom to combine work and care than others. For example, while the availability and accessibility of childcare has increased, the design (increased costs, suboptimal quality) leads to decreased accessibility in some cases (e.g. low-income parents). In addition, accessibility is lower for the self-employed compared to dependent employees.

In relation to leave policies, although the availability and accessibility has grown since the 1990s, the design (length and affordability) of many leave policies is still problematic. Parental leave is unpaid and only a small percentage of collective agreements provides some kind of financial compensation. Unlike many Scandinavian countries, where 'daddy quotas' enable fathers to care for their young children, the Netherlands has just two days paid leave for fathers. Such leave policies limit the alternatives for the one-and-a-half earner model.

Lastly, the availability, accessibility and design of flexible work arrangements have significantly improved in recent years in the Netherlands. New legislation, the protection of part-time work and attention for time/spatial flexibility in relation to new ways of working provides an increasing number of employees with the ability to work flexibly and from home. Yet the degree to which employees can vary their start and end times did not increased much in recent years and not everyone has access to teleworking. Part-time work is a common strategy for women to combine work and care. Men use this strategy less often, particularly due to prevailing norms about the division of paid work and care tasks. Flexible working arrangements are particularly available to highly skilled professionals and are used primarily to work more, and to a much lesser extent to combine work and care. While the self-employed generally have more flexibility and autonomy, this does not always lead to a better work-life balance. The degree of autonomy over working hours differs for the self-employed and they often work long hours (Annink and den Dulk 2012).

These findings may have important social and policy implications. The expectation that people are responsible for providing care and having a paid job may lead, for example to increased time pressure, stress and work-family conflict. The extent to which people are able to combine paid work and family responsibilities has an impact on their physical and psychological wellbeing (Baxter et al. 2007; Kelly et al. 2011). In addition, social inequality has increased in recent years in the Netherlands (Vrooman et al. 2014). While many policies have aimed at reducing gender differences in work and care, these policies can lead to an increase in class differences (Korpi et al. 2013). Significant differences between employees and the self-employed also exist, which can further increase social inequality. Currently in the Netherlands, there is a policy focus on the "big society', with social participation and civic engagement high on the policy agenda. As such, there is an assumption that men and women, high and low-skilled workers and the self-employed combine paid work and caring responsibilities. However, current work-family policy provides people with insufficient capabilities to do so. To empower people to combine work and care, several policy changes are needed. To start, it is necessary to develop policies that better reflect the diversity of society.

Our findings show that despite shifts in attitudes to work and care and changes in work-family policies, different groups of people in society have few alterna- 
tives for combining work and care. Policies that provide a greater number of alternatives increase the likelihood that people are able to combine work and care. With respect to gender, for example, a substantial parttime job or full-time work is often not a viable option for women. For men, taking on a substantial caring responsibility remains unrealistic. More paid paternity leave or a "daddy quota" policy can challenge these prevailing norms and patterns of dominant gender divisions of paid work and care tasks. As we have witnessed in other countries, this leads to greater involvement of fathers in caring for children (Haas and Rostgaard 2011; Tanaka and Waldfogel 2007). In addition, paid parental leave would increase the alternatives around combining work and care for low-income parents. Without paid leave or better access to flexible working arrangements, this group is at a disadvantage for reconciling work and care.

In order for flexible work arrangements to be successful, attitudes around the ideal employee should also be challenged. The use of flexible arrangements should not come at the expense of career opportunities as people use flexibility for care tasks at various times across the life course. This is not only an important task for the government, but also for employers. While some organizations offer a supportive work-life culture, for many organizations, the ideal worker remains the full-time working, always available male worker. Time and career requirements continue to be based on this model. These requirements conflict with finding a good balance between work and family responsibilities and the use of work-family policies. When a culture persists in which visibility and long hours indicate workers' dedication and commitment, workers are forced to make a choice between career opportunities and using leave and flexible work arrangements. A change in organizational culture is often needed to ensure that a combination of career and family responsibilities is a possibility.
The self-employed have fewer capabilities to combine work and care than dependent employees do. In particular, childcare is relatively expensive and therefore less accessible for the low-income self-employed. For this group, making use of leave policies is either not possible or not feasible. Research also shows that many self-employed women work part-time. They choose not to expand their business, in part because of caring responsibilities (Annink and den Dulk 2014). Work-family policies that take account of the various frameworks in which people make choices in reconciling work and care will enhance people's capabilities to combine work and care in a sustainable manner.

\section{【References】}

Aboim, S., 2010, "Gender cultures and the division of labour in contemporary Europe: A cross-national perspective," The Sociological Review, 58(2): 171-96.

Annink, A. and L. den Dulk, 2012, “Autonomy: The panacea for self-employed women's work-life balance?” Community, Work \& Family, 15(4): 1-20.

Annink, A. and L. den Dulk, 2014, De positie van vrouwelijke ZZP'ers in Nederland, State of the art paper, Rotterdam: Erasmus University Rotterdam.

Annink, A., L. den Dulk and B. Steijn, 2015, "Work-family state support for the self-employed across Europe," Journal of Entrepreneurship and Public Policy, 4(2): 187-208.

Baxter, J., M. Gray, M. Alexander, L. Strazdins and M. Bittman, 2007, Mothers and fathers with young children: Paid employment, caring and wellbeing, Canberra, Australia: Australian Department of Families, Community Services and Indigenous Affairs.

Bianchi, S., M. Milkie, L. Sayer and J. Robinson, 2000, "Is Anyone Doing the Housework?: Trends in the Gender Division of Household Labor," Social Forces, 79(1): 191-228.

CBS, 2014a, CBS Statline, Centraal Bureau voor de Statistiek (Statistics Netherlands).

CBS, 2014b, Minder kinderen naar kinderdagverblijven, Webmagazine, 18 February 2014, (http://www.cbs.nl/nl-NL/ menu/themas/dossiers/jongeren/publicaties/artikelen/ archief/2014/2014-4024-wm.htm).

CBS, 2015, CBS Statline, Centraal Bureau voor de Statistiek (Statistics Netherlands). 
Crompton, R., 2006, Employment and the Family: The Reconfiguration of Work and Family Life in Contemporary Societies, Cambridge; New York: Cambridge University Press.

de la Croix, J., A. Houtkoop, E. C. Jurger-van Hoorn, A. J. Machiels-van Es, W. Smits and G. Wiggers, 2014, Arbeid en (mantel)zorg 2014, CAO onderzoek 2014, The Hague: SZW. den Dulk, L., 2001, Work-Family Arrangements in Organisations: A Cross-National Study in the Netherlands, Italy, the United Kingdom and Sweden, Amsterdam: Rozenberg Publishers.

den Dulk, L. and J. De Ruijter, 2008, “Explaining managerial attitudes towards the use of work-life policies in the United Kingdom and the Netherlands," International Journal of Human Resource Management, 19 (7): 1224-38.

den Dulk, L., S. Groeneveld, A. Ollier-Malaterre and M. Valcour, 2013, "National context in work-life research: A multi-level cross-national analysis of the adoption of workplace work-life arrangements in Europe," European Management Journal, 31(5): 478-94.

den Dulk, L. and B. Peper, 2016, "The impact of national policies on work-family experiences," T. D. Allen and L. T. Eby eds., The Oxford Handbook of Work and Family, New York: Oxford University Press, 300-14.

den Dulk, L., B. Peper, N. Cernigoj-Sadar, S. Lewis, J. Smithson and A. van Doorne-Huiskes, 2011, "Work, Family and managerial attitudes and practices in the European Workplace: Comparing Dutch, British and Slovenian financial sector managers," Social Politics, 18(2): 300-29.

ESS, 2010, "Round 5: European Social Survey Data (2010)," Data file edition 3.2, Norwegian Social Science Data Services, Norway - Data Archive and distributor of ESS data.

Fahlén, S., 2014, “Does gender matter? Policies, norms and the gender gap in work-to-home and home-to-work conflict across Europe," Community, Work \& Family, 17(4): $1-21$.

Foley, M., 2015, “Self-Employment after Motherhood: A Temporary Solution or Permanent Shift?” Paper presented at the $6^{\text {th }}$ International Community, Work \& Family conference, Malmö, Sweden, 19-22 May.

Fox, E., G. Pascall and T. Warren, 2009, "Work-family policies, participation, and practices: Fathers and childcare in Europe," Community, Work \& Family, 12(3): 313-26.

Fukkink, R. G., M. J. J. G. Deynoot-Schaub, K. O. W. Helmerhorst, I. Bollen and J. M. A. Riksen-Walraven, 2013, Pedagogische kwaliteit van de kinderopvang voor 0- tot 4-jarigen in Nederlandse kinderdagverblijven in 2012, Nijmegen, Amsterdam: Nederlands Consortium Kinderopvang Onder- zoek.

Gornick, J. and M. Meyers, 2004, "Welfare Regimes in Relation to Paid Work and Care," J. Zollinger and Elke Holst eds., Changing Life Patterns in Western Industrial Societies, Netherlands: Elsevier Science Press, 45-67.

Grunow, D., F. Schulz and H. Blossfeld, 2012, "What determines change in the division of housework over the course of marriage?" International Sociology, 27(3): 289-307.

Haas, L., and M. O’Brien, 2010, “New Observations on How Fathers Work and Care: Introduction to the Special IssueMen, Work and Parenting-Part I," Fathering: A Journal of Theory, Research, and Practice about Men as Fathers, 8(3): 271-75.

Haas, L. and T. Rostgaard, 2011, "Fathers' rights to paid parental leave in the Nordic countries: Consequences for the gendered division of leave," Community, Work \& Family, 14(2): 177-95.

Hegewisch, A. and J. C. Gornick, 2011, “The impact of workfamily policies on women's employment: A review of research from OECD countries," Community, Work \& Family, 14(2): 119-38.

Hobson, B. ed., 2014, Worklife Balance: The Agency and Capabilities Gap, Oxford: Oxford University Press.

Hobson, B., S. Fahlén and J. Takács, 2011, “Agency and capabilities to achieve a work-life balance: A comparison of Sweden and Hungary," Social Politics, 18(2): 168-98.

Kelly, E. L., P. Moen and E. Tranby, 2011, “Changing Workplaces to Reduce Work-Family Conflict: Schedule Control in a White-Collar Organization," American Sociological Review, 76(2): 265-90.

Keuzenkamp S., C. Hillebrink, W. Portegijs and B. Pouwels, 2009, Deeltijd (g)een probleem, The Hague: SCP.

Klink, J. J. Van der, U. Bültmann, S. Brouwer, A. Burdorf, A. W. B. Schaufeli, F. R. H. Zijlstra and G. J. van der Wilt, 2011, "Duurzame inzetbaarheid bij oudere werknemers, werk als waarde," Gedrag \& Organisatie, 24(4): 342-56.

Korpi, W., T. Ferrarini and S. Englund, 2013, “Women's Opportunities under Different Family Policy Constellations: Gender, Class, and Inequality Tradeoffs in Western Countries Re-examined," Social Politics: International Studies in Gender, State \& Society, 20(1): 1-40.

Kremer, M., 2006, How Welfare States Care: Culture, Gender and Parenting in Europe, Amsterdam: Amsterdam University Press.

Luijn, H. van and S. Keuzenkamp, 2004, Werkt verlof? Het gebruik van regelingen voor verlof en aanpassing van de arbeidsduur, The Hague: SCP. 
MacEachen, E., J. Polzer and J. Clarke, 2008, “' You are free to set your own hours': Governing worker productivity and health through flexibility and resilience," Social Science and Medicine, 66: 1019-33.

Merens, A. and M. Van den Brakel, 2014, Emancipatiemonitor 2014, The Hague: Sociaal en Cultureel Planbureau/Centraal Bureau voor de Statistiek.

Misra, J., M. Budig and I. Boeckmann, 2011, “Work-family policies and the effects of children on women's employment hours and wages," Community, Work \& Family, 14(2): 139-57.

Neilson, J. and M. Stanfors, 2014, “It's About Time! Gender, Parenthood, and Household Divisions of Labor Under Different Welfare Regimes," Journal of Family Issues, 35(8): 1066-88.

Ollier-Malaterre, A., 2009, "Organizational work-life initiatives: Context matters: France compared to the UK and the US," Community, Work \& Family, 12(2): 159-78.

Peper, B., A. van Doorne-Huiskes and L. den Dulk, 2009, "Work-family policies in a contradictory culture: A Dutch financial sector corporation," S. Lewis, J. Brannen and A. Nilsen eds., Work, Family and Organisations in Transition: A European Perspective, Policy Press.

Peters, P., L. den Dulk and T. van der Lippe, 2009, “The effects of time-spatial flexibility and new working conditions on employees' work-life balance: The Dutch case," Community, Work \& Family, 12(3): 279-97.

Peters, P., L. den Dulk and J. de Ruijter, 2010, “'May I work from home?': Views of the employment relationship reflected in line managers' telework attitudes in six financial-sector organizations," Equality, Diversity and Inclusion, 29(5): 517-31.

Portegijs, W., M. Cloïn and A. Merens, 2014, Krimp in de kinderopvang: Ouders over kinderopvang en werk, Den Haag: Sociaal en Cultureel Planbureau.

Raven, J., P. Achterberg, R. Van der Veen and M. A. Yerkes, 2011, “An Institutional Embeddedness of Welfare Opinions?: The Link between Public Opinion and Social Policy in the Netherlands (1970-2004)," Journal of Social Policy, 40: 369-86.

Robeyns, I., 2005, “The Capability Approach: A theoretical Survey," Journal of Human Development, 6(1): 93-117.

Sen, A., 1992, Inequality Reexamined, Cambridge, Mass: Harvard University Press.

Smulders, P., K. Kraan and F. Pot, 2011, “Telewerkers vormen een elite," Economisch Statistische Berichten, 96(4616): 4935.

Takahashi, M., S. Kamano, T. Matsuda, S. Onode and K. Yoshizumi, 2014, "Worklife balance in Japan: New policies, old practices," B. Hobson ed., Worklife Balance: The Agency and Capabilities Gap, Oxford: Oxford University Press, 92125.

Tanaka, S. and J. Waldfogel, 2007, "Effects of parental leave and work hours on fathers' involvement with their babies," Community, Work \& Family, 10(4): 409-26.

Thompson, C. A., L. L. Beauvais and K. S. Lyness, 1999, "When work-family benefits are not enough: The influence of work-family culture on benefit utilization, organizational attachment, and work-family conflict," Journal of Vocational Behavior, 54: 392-415.

Van Echtelt, P., R. Schellingenhout and M. de Voogd-Hamelink, 2015, Vraag naar arbeid 2015, The Hague: Sociaal en Cultureel Planbureau.

Van Wel, F. and T. Knijn, 2006, “Transitional phase or a new balance? Working and caring by mothers with young children in the Netherlands," Journal of Family Issues, 27(5): 633-51.

Visser, J., 2002, “The first part-time economy in the world: A model to be followed?" Journal of European Social Policy, 12(1): 23-42.

Vlasblom, J. D., P. van Echtelt and M. de Voogd-Hamelink, 2015, Aanbod van arbeid 2014, Arbeidsdeelname, flexibilisering en duurzame inzetbaarheid, The Hague: Sociaal en Cultureel Planbureau.

Vries, J. de and F. van der Mooren, 2011, "Inkomen en de combinatie Arbeid en Zorg," Sociaaleconomische Trends, 2011(1): 45-55

Vrooman, C., M. Gijsberts and J. Boelhouwer, 2014, Verschil in Nederland, Sociaal en Cultureel Rapport 2014, The Hague: Sociaal en Cultureel Planbureau.

Yerkes, M. A., 2009, "Part-time Work in the Dutch Welfare State: The Ideal Combination of Work and Care?" Policy and Politics, 37(4): 535-52.

Yerkes, M. A., 2014, "Collective Protection for New Social Risks: Childcare and the Dutch Welfare State," Journal of Social Policy, 43(04): 811-28.

Yerkes, M. A. and K. Tijdens, 2010, "Social risk protection in collective agreements: Evidence from the Netherlands," European Journal of Industrial Relations, 16(4): 369-83. 